PSIKOPEDAGOGIA, Vol. 1, No. 1, Juni 2012

ISSN: 2301-6167

\title{
BULLYING DAN UPAYA MEMINIMALISASIKANNYA
}

\section{BULLYING AND EFFORTS TO MINIMIZE}

\author{
Sucipto
}

Prodi BK FKIP Universitas Muria Kudus

\begin{abstract}
Abstrak
Bullying merupakan aksi negatif yang seringkali agresif dan manipulatif, dilakukan satu orang bahkan lebih terhadap orang lain selama kurun waktu tertentu yang bernuatan fisik dan non fisik (Psikologi Plus volume V no.3). Hubungan pelaku dan korban bullying biasanya merupakan hubungan sejawat atau teman sebaya, misalnya teman sekelas, antara kakak kelas dan adik kelas, antara senior dan junior. Bullying dapat berbentuk fisik seperti pukulan, tendangan,tamparan, dorongan, serta serangan fisik lainnya. Yang berbentuk non fisik bullying dapat dibedakan menjadi 2 (dua), yaitu verbal maupun nonverbal. Ejekan, panggilan dengan sebutan tertentu, ancaman, penyebaran berita rahasia korban, perkataan yang memalukan tergolong aksi verbal. Ekspresi wajah yang tidak menyenangkan dan bahasa tubuh yang mengancam merupakan aksi nonverbal. Jadi dari perbuatan bullying perbuatan tersebut membuat para pelaku lebih berani berbuat yang lebih nekat terhadap korban yang bahkan tidak mungkin dapat berujung tindak kriminalitas berat, sedangkan bagi sang korban merasa harga dirinya sangat rendah sekali, tidak percaya diri dan tidak bahagia. Upaya meminimalisasikan bullying, yaitu: 1) cermati gejala-gejala perubahan anak, dan segeralah lakukan pendekatan padanya, 2) tenanglah dalam bertindak, sambil meyakinkan anak bahwa is telah mendapat perlindungan dari perilaku bullying mendatang, 3) laporkan kepada guru/ pihak sekolah untuk segera dilakukan penyelidikan, 4) meminta konselor ( guru BK) sekolah melakukan penyelidikan tentang apa yang telah terjadi, 5) meminta pihak sekolah untuk memberikan info tentang apa yang sebenarnya telah terjadi, dan 6) mengajarkan anak cara-cara menghadapi bullying.
\end{abstract}

Kata kunci: bullying; upaya meminimalisasikannya

\begin{abstract}
Bullying is a negative action that is often aggressive and manipulative, carried one person even more for others during the period in which the physical and non-physical bernuatan (Psychology Plus volume $V$ no.3). Relationship perpetrators and victims of bullying usually a peer or peer relationships, for example classmates, between seniors and juniors, between senior and junior. Bullying may be physical such as a punch, kick, slap, push, as well as other physical attacks. In the form of non-physical bullying can be divided into 2 (two), namely verbal and nonverbal. Mockery, calls with a particular designation, threats, spread news of victims secret, shameful words belong verbal action. Unpleasant facial expressions and body language that threatens a nonverbal action. So the act of bullying act make players more willing to do more reckless against victims who may not even be able to lead a heavy crime, whereas for the victim feel very low self-esteem, insecure and unhappy. Efforts minimize bullying, namely: 1) look at the symptoms change in the child, and immediately do approach him, 2) cool it in the act, while assuring the child that is already protected from bullying behavior upcoming, 3) report to the teacher / school to immediately investigation, 4) require counselors (teacher BK) school conducted an investigation about what had happened, 5) asked the schools to provide information about what had happened, and 6) to teach children how to deal with bullying.
\end{abstract}

Keywords: bullying; efforts to minimize 


\section{PENDAHULUAN}

Bullying bisa terjadi di berbagai setting seperti di sekolah, di rumah, di pondok pesantren, di tempat penitipan anak, di tempat kursus/les, di kantor, di area tempat bermain, dan lain sebagainya. Dalam tulisan ini digunakan beberapa metode untuk mendapatkan sumber-sumber informasi, antara lain dari buku referensi, majalah psikologi plus, internet, serta dari sumber-sumber pelaku (baik korban maupun pelaku) dari perilaku Bullying. Pengumpulan data lapangan untuk mengungkap bullying dari pelaku maupun korban digunakan pedoman wawancara dan pedoman pengamatan.

Suatu hari ketika hendak berangkat sekolah, scorang siswa mengeluh sakit kepala, mual dan sakit perut. Ia menolak iiiasuk sekolah karcna sakit. Pada saat dibawa ke doktcr tidak ditemukan gejala penyakit dan setelah beberapa jam di rumah tampak baikbaik saja, seperti tidak sakit sedikitpun. Rupanya anak ini sedang membuat alibi untuk tidak masuk sekolah.

Peristiwa yang dialami seseorang anak di atas adalah sebuah gejala yang hams diwaspadai bersama, apalagi terjadi berulang kali. Identifikasinya semakin jelas jika muncul perubahan sangat signifikan pada anak. Misalnya, awalnya ia sangat menyukai sekolah tetapi kemudia ia tidak ingin ke sekolah. Ada sesuatu yang menjadi momok menakutkan bagi anak dan ini perlu digali lebih jauh. Salah satu penyebab yang biasanya terjadi adalah adanya kekerasan antar sesame teman, atau yang biasa dikenal dengan istilah bullying.
Fenomena kekerasan di sekolah yang dilakukan oleh teman sebaya di Indonesia khususnya semakin banyak bermunculan. Mulai dari peristiwa IPDN (Institut Pernerintahan Dalam Negeri) dengan klimaks kejadian praja Klift Muntu akibat dianiyaya oleh seniornya di lingkungan kampus dalam rangka pemberian hukuman -atau dalam istilah mereka sendiri, 'pembinaan' atau 'koreksi'- atas kesalahan yang dilakukan sang praja. Ini bukan yang pertama kalinya; menurut penelitian yang dilakukan oleh seorang dosen IPDN, terdapat lebih dari 30 kasus kematian tak wajar yang dicurigai disebabkan oleh penganiayaan. Kasus-kasus itu terjadi dalam rentang waktu yang panjang, dan diduga telah menjadi tradisi di institut itu.

Kasus lainnya yaitu seorang siswa SLTP di Bekasi yang gantung diri karena tidak kuat menerima ejekan dari teman-temannya sebagai anak tukang bubur. Bahkan yang terbaru adalah sekolah STIP (Sekolah Tinggi Ilmu Pelayaran) yang juga memakan korban. Agung Bastian Gultom yang tewas akibat dianiyaya seniornya, atau bahkan Gank Nero dari para remaja perempuan yang melakukan kekerasan terhadap teman sebaya.

IPDN tidak sendirian. Beberapa tahun sebelumnya juga sempat ramai diperdebatkan aktivitas `perploncoan' di sebagian universitas yang dianggap menyiksa dan menganiaya mahasiswa baru. Dalam skala yang lebih kecil, hubungan siswa senior-junior yang tidak sehat juga terjadi di sekolah-sekolah menengah. Hal senada juga diungkapkan oleh Diena Haryana (2010) dari SEJIWA dalam presentasinya beliau mengatakan bahwa telah 
banyak korban berjatuhan akibat adanya bullying dan tindak kekerasan di sekolahsekolah yang ada di Indonesia. Hasil penelitiannya menunjukkan hal itu.

Kekerasan yang sering terjadi di sekolah itu adalah corporal punishment, bullying, pelecehan seksual, penggunaan senjata, dan pembentukan geng-geng. Namun dari semuanya itu yang paling terbanyak adalah bullying dan corporal punishment.

Corporal punishment adalah hukuman yang paling banyak dilakukan oleh guru di sekolah terhadap siswa dengan menggunakan kekerasan dengan sebuah alasan karena hendak mendisiplinkan siswa. Misalnya memukul tangan dengan penggaris, menjambak rambut karena terlalu panjang, menyuruh push up karena terlambat, menampar kepala karena tak dapat membaca dengan lancar.

Bullying, adalah kata kunci untuk mendeskripsikan semua gejala itu. Apa sebenarnya bullying? Perbuatan apa saja yang dikategorikan sebagai bullying? Mengapa pelaku melakukan bullying, dan apa dampaknya bagi korban?

\section{STUDI LITERATUR}

Ada banyak definisi mengenai bullying, terutama yang terjadi dalam konteks lain (tempat kerja, masyarakat, komunitas virtual). Namun di sini penulis akan membatasi konteksnya dalam school bullying. Riauskina, Djuwita, dan Soesetio (2005) mendefinisikan school bullying sebagai perilaku agresif yang dilakukan berulang-ulang oleh seorang/sekelompok siswa yang memiliki kekuasaan, terhadap siswa/siswi lain yang lebih lemah, dengan tujuan menyakiti orang tersebut. Mereka kemudian mengelompokkan perilaku bullying ke dalam 5 kategori:

a. Kontak fisik langsung (memukul, mendorong, menggigit, menjambak, menendang, mengunci seseorang dalam ruangan, mencubit, mencakar, juga termasuk memeras dan merusak barangbarang yang dimiliki orang lain)

b. Kontak verbal langsung (mengancam, mempermalukan, merendahkan, mengganggu, memberi panggilan nama (name-calling), sarkasme, merendahkan (put-downs), mencela/mengejek, mengintimidasi, memaki, menyebarkan gosip)

c. Perilaku non-verbal langsung (melihat dengan sinis, menjulurkan lidah, menampilkan ekspresi muka yang merendahkan, mengejek, atau mengancam; biasanya diertai oleh bullying fisik atau verbal).

d. Perilaku non-verbal tidak langsung (mendiamkan seseorang, memanipulasi persahabatan sehingga menjadi retak, sengaja mengucilkan atau mengabaikan, mengirimkan surat kaleng).

e. Pelecehan seksual (kadang dikategorikan perilaku agresi fisik atau verbal).

Dan beberapa penelitian sebelunmya, juga ditemukan perbedaan umur dan gender yang dapat mempengaruhi perilaku bullying. Pada usia 15 tahun, anak laki-laki ditemukan lebih cenderung mem-bully dengan kontak fisik langsung, sementara anak perempuan 
lebih cenderung mem-bully dengan perilaku tidak langsung. Namun tidak ditemukan perbedaan dalam kecenderungan melakukan bullying verbal langsung. Pada usia 18 tahun, kecenderungan anak laki-laki mem-bully dengan kontak fisik menurun tajam, dan kecenderungannya untuk menggunakan perilaku verbal langsung dan perilaku tidak langsung meningkat, meskipun anak perempuan masih tetap lebih tinggi kecenderungannya dalam hal ini.

\section{Apakah perilaku Bullying?}

Bullying terjadi ketika seseorang merasa teraniaya, takut, terintimidasi, oleh tindakan seseorang baik secara verbal, fisik atau mental. Ia takut bila perilaku tersebut akan terjadi lagi, dan is merasa tak berdaya mencegahnya. (Andrew Mellor, antibullying network, univ. of edinburgh, scotland).

Beberapa macam tindakan Bullying adalah:

a. Psikologis seperti memfitnah, mempermalukan, menakut-nakuti, menolak, menghina, melecehkan, mengecilkan, mentertawakan, mengancam, menyebarkan gosip. mencibir, dan mendiamkan

b. Fisik seperti menendang, menempeleng, memukul, mencubit, menjotos, menjewer, lari keliling lapangan, push up, bersihkan WC, dan memalak.

c. Verbal seperti berteriak, meledek, mengatangatai, name calling, mengumpat, memarahi, dan memaki.

Bullying perlu kita cermati karena tak ada seorang pun punya hak dan alasan untuk membullying orang lain. Serta tak ada seorangpun layak menjadi korban bullying.

Gejala-gejala tengah terjadinya tindakan bullying pada siswa-siswa di sekolah adalah:

a. Adanya penurunan pada penampilan akademisnya.

b. Adanya penurunan pada kehadirannya di sekolah.

c. Hilangnya minat pada pekerjaan sekolah / PR .

d. Sulit berkonsentrasi pada pekerjaan sekolah.

e. Berkurangnya minat pada kegiatankegiatan sekolah.

f. Drop out dari kegiatan yang tadinya dia sukai.

Patut dicatat bahwa ini adalah hasil penelitian di luar negeri yang belum tentu sesuai dengan kondisi pendidikan di Indonesia. Riauskina dkk. menemukan dalam penclitiannya pada 2 SMA di Jakarta bahwa kecenderungan untuk melakukan kontak fisik langsung masih terlihat pada anak laki-laki di usia 18 tahun.

\section{PEMBAHASAN}

Seperti yang telah terjadi pada kasus IPDN dan sebagian kasus-kasus lainnya, bullying adalah sebuah siklus, dalam artian pelaku saat ini kemungkinan besar adalah korban dari pelaku bullying sebelumnya. Ketika menjadi korban, mereka membentuk skema kognitif yang salah bahwa bullying bisa 'dibenarkan' meskipun mereka merasakan dampak negatifnya sebagai korban. Hal ini tampak dalam sebuah potongan wawancara pra-survei: 
Tanya. ... kalo nanti kalo kalian udah kelas dua gitu, mungkin ga jadi kaya mereka sekarang...?

Jawab: ...tergantung si, tergantung ade kelasnya... kalo ade kelasnya nyolot ya gue marahin...

Mengapa seorang korban bisa kemudian menerima, bahkan menyetujui perspektif pelaku yang pernah merugikannya? Salah satu alasannya dapat diurai dari hasil survei: sebagian besar korban enggan menceritakan pengalaman mereka kepada pihak-ipihak yang mempunyai kekuatan untuk mengubah cara berpikir mereka dan menghentikan siklus ini, yaitu pihak sekolah dan orangtua. Korban biasanya merahasiakan bullying yang mereka derita karena takut pelaku akan semakin mengintensifkan bullying mereka. Akibatnya, korban bisa semakin menyerap 'falsafah' bullying yang didapat dari seniornya. Dalam skema kognitif korban yang diteliti oleh Riauskina dkk., korban mempunyai persepsi bahwa pelaku melakukan bullying karena Tradisi

a. Balas dendam karena dia dulu diperlakukan sama (menurut korban laki-laki)

b. Ingin menunjukkan kekuasaan

c. Marah karena korban tidak berperilaku sesuai dengan yang diharapkan

d. Mendapatkan kepuasan (menurut korban perempuan)

e. Iri hati (menurut korban perempuan)

Adapun korban juga mempersepsikan dirinya sendiri menjadi korban bullying karena

a. Penampilan menyolok

b. Tidak berperilaku dengan sesuai

c. Perilaku dianggap tidak sopan

\section{d. Tradisi}

Salah satu dampak dari bullying yang paling jelas terlihat adalah kesehatan fisik. Beberapa dampak fisik yang biasanya ditimbulkan bullying adalah sakit kepala, sakit tenggorokan, flu, batuk, bibir pecah-pecah, dan sakit dada. Bahkan dalam kasus-kasus yang ekstrim seperti insiden yang terjadi di IPDN, dampak fisik ini bisa mengakibatkan kematian.

Dampak lain yang kurang terlihat, namun berefek jangka panjang adalah menurunnya kesejahteraan psikologis (psychological wellbeing) dan penyesuaian sosial yang buruk. Dari penelitian yang dilakukan Riauskina dkk., ketika mengalami bullying, korban merasakan banyak emosi negatif (marah, dendam, kesal, tertekan, takut, malu, sedih, tidak nyaman, terancam) namun tidak berdaya menghadapinya. Dalam jangka panjang emosiemosi ini dapat berujung pada munculnya perasaan rendah diri bahwa dirinya tidak berharga.

Kesulitan menyesuaikan diri dengan lingkungan sosial juga muncul pada para korban. Mereka ingin pindah ke sekolah lain atau keluar dari sekolah itu, dan kalaupun mereka masih berada di sekolah itu, mereka biasanya terganggu prestasi akademisnya atau sering sengaja tidak masuk sekolah.

Yang paling ekstrim dari dampak psikologis ini adalah kemungkinan untuk timbulnya gangguan psikologis pada korban bullying, seperti rasa cemas berlebihan, selalu merasa takut, depresi, ingin bunuh diri, dan gejala-gejala gangguan stres pasca-trauma (post-traumatic stress disorder). Dari 2 SMA 
yang diteliti Riauskina dick., hal-hal ini juga dialami korban, seperti merasa hidupnya tertekan, takut bertemu pelaku bullying, bahkan depresi dan berkeinginan untuk bunuh diri dengan menyilet-nyilet tangannya sendiri!

Dari informasi di atas, kita dapat melihat bagaimana perilaku bullying sebenarnya sudah sangat meluas di dunia pendidikan kita tanpa terlalu kita sadari bentuk dan akibatnya. Dalam bagian ke-2, penulis akan menelusuri beberapa sumber lebih jauh lagi untuk melihat karakteristik pelaku bullying, mitos dan fakta tentang bullying, serta bagaimana menghadapi bullying, baik bagi korban, siswa lain yang menonton, maupun bagi pihak sekolah atau orangtua.

Bullying merupakan serangkaian aksi negatif yang seringkali agrcsif dan manipulatif yang dilakukan oleh satu/lebih orang terhadap orang lain/beberapa orang selama kurun waktu tertentu bermuatan kekerasan dan melibatkan ketidakseimbangan kekuatan. Pelaku biasanya mencuri-curi kesempatan dalam melakukan aksinya dan bermaksud membuat orang lain merasa tidak nyaman/terganggu, sedangkan korban biasanya juga menyadari bahwa aksi ini akan berulang menimpanya. Kata bullying familiar dalam bahasa Inggris (etimologi dari kata bully, barangkali berasal dari kata middle dutch, boele yang bermakna first sweet heart, kemudian fine fello, kemudian bluestere: Encarta World English Dictionary,1999). Di samping itu beberapa pendapat menyatakan bullying berasal dari kata bull yang berarti sapi jantan sebagai lambang kekuatan, adapula yang menyatakan bull mengacu pada hubungan pertemanan atau teman sebaya. Terlepas dari beragam pendapat tersebut, hubungan pelaku dan korban bullying merupakan teman sejawat/teman sebaya, misalnya teman sekelas, adik kelas-kakak kelas, senior-junior sehingga sebenarnya bullying tidak saja berkemungkinan di sekolah atau di rumah, namun juga berpeluang terjadi di tempat kerja maupun penjara.

Pelaku dan korban biasanya saling mengenal, pada mulanya bukan `musuh', dan kekuatan pelaku jauh lebih besar dari pada korban, sehingga korban dalam posisi tak berdaya. Bullying dengan setting di sekolah dapat terjadi di kelas, misalnya yang terjadi pada anak SD, korban tidak akan diajak bermain kalau tidak menyerahkan uang saku dalam jumlah tertentu setiap harinya. Bullying sering juga terjadi di kamar mandi, kantin, halaman sekolah, atau perjalanan dari/pergi dan sekolah. Kekerasan ini dapat dilakukan saat jam pelajaran di kelas, istirahat, jam ekstrakurikuler, orientasi bagi murid baru, bahkan ada pula saat study tour.

Bullying dapat berbentuk fisik, seperti pukulan, tendangan, tamparan, dorongan, serta serangan fisik lainnya. Yang berbentuk secara non fisik, bullying dapat dilakukan secar verbal dan nonverbal, ej ekan, panggilan dengan sebutan tertentu, ancaman, penyebaran gosip, perkataan yang mempermalukan tergolong aksi verbal. Ekspresi wajah yang tidak menyenangkan dan bahasa tubuh yang mengancam merupakan aksi nonverbal yang dilakukan secara langsung. Sedangkan pengabaian, 
penyingkiran dari kelompok, serta pengiriman pesan tertulis yang bernada mengganggu, dan merebut pacar, termasuk aksi nonverbal secara tidak langsung.

Yang sedang marak saat ini adalah penulisan kesaksian yang mengganggu (bisa palsu atau membuka rahasia) di friendster. Bullying bisa pula berbentuk pengrusakan atau perampasan barang milik korban, seperti penyobekan, pencoretan, pembantingan, perebutan, dan pencurian. Perilaku laki-laki cenderung lebih banyak aksi fisik dibandingkan perempuan yang lebih memilih melancarkan aksi nonfisik.

Bullying melibatkan beberapa fihak. Pertama, tentu saja pelaku yang biasanya bertujuan mendapatkan sesuatu yang diinginkan, mendapatkan kepuasan setelah menunjukkan kekuatan, balas dendam, namun bisa juga tadinya ia iseng, coba-coba, dan 'berhasil, sehingga ingin mengulang kembali keberhasilannya. Pelaku ada yang memang terkenal bengal, prestasi belajar kurang baik, dan suka membuat onar, sehingga orang lain menganggap tidak aneh apabila melakukan bullying. Namun, adapula pelaku yang merupakan anak berprestasi baik dan tampak alim yang mampu menutupi aksinya sedemikian rupa, sehingga orang lain tidak menyangka bila ia adalah pelaku. Para pelaku adapula yang juga menjadi korban pada saat yang sama dalam setting berbeda, misalnya di sekolah menjadi pelaku, tapi di rumah menjadi korban.

Pihak berikutnya adalah korban. Korban ada yang bersifat pasif yang senantiasa menuruti permintaan pelaku, adapula yang profokatif, mencoba melawan dan menunjukkan perilaku tertentu secara menonjol yang memancing pelaku melakukan aksi kekerasan. Korban biasanya memiliki karakteristik tertentu yang menarik perhatian atau oleh pelaku "dianggap berbeda" dibandingkan teman sebayanya, sehingga memicu pelaku untuk melakukan bullying. Korban bisa dianggap berbeda secara fisik, seperti memiliki paras wajah, warna kulit, susunan gigi, jenis rambut, atau tinggi badan dengan ukuran tertentu. Korban dapat pula menunjukkan perilaku tertentu, seperti cara berjalan, logat bicara. Latar belakang korban, seperti kondisi keluarga, status sosial ekonomi, lingkungan tempat tinggal, dll.

Kesalahan pada korban dapat pula dicaricari, misalnya dianggap melanggar 'tradisi' dengan berpenampilan yang dirasa terlalu menor, terlalu rapi karena memakai jel rambut dan minyak wangi, tidak 'nongkrong' seperti yang lain, dan sebagainya. Korban yang merahasiakan tindakan bullying terhadapnya, biasanya memiliki alasan sebagai berikut. Bila bercerita kepada orang lain ia takut akan terjadi sesuatu yang lebih buruk dan takut dikucilkan. Korban dapat pula tidak percaya pada guru, tidak ingin membuat orang tua kawatir, bahkan ada pula diantaranya yang merasa bahwa dirinya juga patut disalahkan.

Pihak ketiga yang terlibat adalah bystanders. Bystanders terdiri dari 4 tipe, sidekick, reinforces, outsider, atau defender. Peran bystanders sebetulnya berkontribusib menentukan apakah bullying akan berlanjut atau tidak. Kekuatan bystanders dapat menghentikan bullying, namun parahnya bila 
mereka acuh tak acuh atau bahkan membantu dan menguatkan aksi pelaku, bullying pun tak terbendung.

Bullying dapat mengakibatkan korban merasa cemas, mengalami gangguan tidur, sedih berkepanjangan, menyalahkan diri sendiri, depresi, bahkan yang paling parah bunuh din. Terkait dengan aktivitas sekolah, korban dapat pula sering absen, terisolasi secara social, prestasi menurun, atau mengalami drop-out. Beberapa penelitiin pun menunjukkan bahwa korban bullying pada 4 tahun berikutnya berpoensi menjadi pelaku. Sedangkan para pelaku bullying, mereka beresiko tinggi terlibat kenakalan dan masalah kriminal serius. Tidak hanya sampai disitu, bullying juga meresahkan orang tua dan masyarakat ketika terjadi di sekolah, tingkat kepercayaan mereka pada institusi pendidikan menjadi menurun.

Sejak tahun 1970-an, bullying telah dikenal sebagai penyakit social di beberapa Negara. Hal ini merupakan sebagian dampak dari bebcrapa peneliti*n yang secara sistematis telah dilakukan tahun 1970-an, dimulai dengan penelitian Olwcus di Scandinavia $(1978,1993)$, dan berlanjut di Eropa, Amerika, Australia, Jepang. Di Jepang, kekerasan ini dikenal dengan dime, menyeruak pada tahun 1984 ditandai dengan 16 peristiwa bunuh diri yang terkait dengan bullying.

Di Amerika Serikat, meskipun bullying sangat popular, namun tidak mendapatkan perhatian sebesar di Jepang, karena terkacaukan dengan beragam bentuk kekerasan lain di sekolah yang juga marak terjadi. Suatu penelitian yang dilakukan pada sejumlah 4092 siswa usia 10-12 tahun di 20 sekolah menengah pertama di Portugal memberikan gambaran bahwa resiko tinggi menjadi korban bullying mengarah pada lakilaki dari kelas sosial ekonomi bawah.

Sementara itu penelitian terhadap 238 siswa kelas tujuh Taiwan bahwa sebagian responden telah menjadi korban bullying sejak pertama kali masuk sekolah menengah pertama. Aksi verbal dan fisik merupakan tipe kekerasan yang paling sering ditemui. Penelitian dengan self dan peer-report measure ini juga menunjukkan bahwa siswa laki-laki lebih banyak terlibat dalam kasus bullying fisik dan verbal daripada siswa perempuan.

Terkait dengan penanganan bullying, di Norwegia, menteri pendidikan setempat memulai kampanye nasional melawan bullying pada tahun 1983. Bersamaan dengan kampanye ini, dilakukan penelitian besar secara longitudional yang melibatkan 2500 siswa selama 2,5 tahun. Hasilnya menunjukkan bahwa terdapat penurunan angka kejadian bullying sebesar 50\% setclah 2 tahun pertama dilaksanakannya program kampanye. Pada tahun 2000, menteri pendidikan juga mengembangkan jaringan nasional bagi para professional terkait dengan mengembangkan lembaga yang menangani bullying dan problem perilaku siswa lainnya.

Lain halnya di Belanda, mulai tahun 1970-an, para psikolog mulai mengusulkan kebijakan untuk menangani bullying. Pada tahun 1992, seorang peneliti mengemukakan bahwa terdapat $25 \%$ dari populasi siswa sekolah dasar(385.000 anak) menjadi korban 
bullying. Sejak saat itu, National Education Protocol Against Bullying

dibentuk,dengan menyelenggarakan program pelatihan ketrampilan social untuk pelaku dan korban, sosialisasi informasi pada guru dan orang tua. Pengadaan tenaga konselor, kerja sama dengan sekolah untuk menyepakati melawan tindakan bullying.

Sedangkan di Hongkong , caramenangani bullying dengan taktif supresif, seperti menceramahi pelaku, mengundang orang tua pelaku, mengundang orang tua ke sekolah, ternyata kurang efektif dibanding-kan dengan melakukan strategi antibullying secara komprehensif, seperti bermanfaat melatih siswa mengembangkan kompetensi diri dan ketrampilan sosial, sementara hubungan baik orang tua-guru bermanfaat sebagai strategi anti kekerasan.

Mengingat begitu memprihatin-kannya aksi bullying, waspadalah ketika anak atau remaja di sekitar anda terdapat tanda-tanda seperti terdapat luka fisik, baju sebagian hilang atau sobek, mencuri uang, sebagian barang hilang, mood berubah-ubah, tidak bahagia, prestasi menurun, enggan ke sekolah, sering tidak masuk, tidak punya teman, barangkali is menjadi korban bullying.

Atau, bila anak anda diusianya yang masih sangat muda sudah mulai menunjukkan tanda suka merendahkan teman, dengan sengaja mengisolasi seorang kawan untuk tidak bermain bersama, atau memperlihatkan keenggaran berbagi dengan sebayanya, segeralah ajak dia berdialog, mulailah mencermati aktivitasnya sehari-hari, berkomunikasilah dengan teman-temannya, serta berdiskusilah dengan wali kelas dan guru bimbingan dan konseling di sekolah, tentunya dengan tanpa meninggalkan intro speksi diri:

Bullying merupakan permasalahan yang sudah mendunia, tidak hanya di Indonesia saja, tetapi juga di Negara-negara maju seperti di Amerika serikat, Jepang, dan Eropa. National Mental Health and Education Centre tahun 2004 di Amerika diperoleh data bahwa bullying merupakan bentuk kekerasan yang umumnya terjadi dalam lingkungan social, antara $15 \%$ dan $30 \%$ siswa adalah pelaku bullying dan korban bullying.

Kita sering melihat aksi anak-anak mengejek, mengolok-olok atau mendorong teman. Perilaku tersebut dianggap sebagai hal yang sangat biasa, sebatas bentuk relasi social antar anak, padahal hal tersebut adalah bentuk perilaku bullying. Kita sangat tidak menyadari konsekuensi yang terjadi jika anak mengalami bullying. Oleh sebab itu berbagai pihak harus memahami apa dan bagaimana bullying itu sehingga dapat secara komprehensif melakukan pencegahan.

Bullying adalah pengalaman yang biasa dialami oleh banyak anak-anak dan remaja di sekolah. Perilaku bullying dapat berupa ancaman fisik dan nonfisik, atau verbal. Bullying terdiri dari perilaku langsung sepeeti mengejek, mengancam, mencela, memukul, dan merampas yang dilakukian oleh satu atau lebih siswa kepada korban atau anak yang lain. Selain itu bullying dapat berupa perilaku tidak langsung misalnya, dengan mengisolasi atau sengaja menjauhkan orang yang dianggap berbeda. 
Baik langsung maupun tidak langsung pada dasarnya bullying adalah bentuk intimidasi fisik atau psikologis yang terjadi berkali-kali dan secara terus menerus membentuk pola kekerasan, misalnya menarik rambut, meninju, memukul, mendorong (fisik); menolak, mereoro, mengisolasi atau menjauhkan, menekan, memeras, memfitnah, menghina, dan adanya deskriminasi berdasarkan ras, ketidakmampuan dan etnik (emosional). Memberikan nama panggilan, mengejek dan menggosip (verbal).

Eksibisionisme dan adanya pelecehan seksual (seksual). Bully atau pelaku bullying adalah seseorang yang secara langsung melakukan agresi baik fisik, verbal, atau psikologis kepada orang lain dengan menunjukkan kekuatan atau mendemonstrasikan kepada orang lain.

Kebanyakan perilaku bullying berkembang dari faktor lingkungan yang kompleks. Tidak ada faktor tunggal menjadi penyebab munculnya bullying. Faktor penyebab bullying antara lain: 1) faktor keluarga: anak yang melihat orang tuanya atau anak yang mengalami bullying sering tergoda mngembangkan perilaku bullying juga. Ketika anak menerima pesan negatif berupa hukuman fisik di rumah, mereka mengembangkan konsep diri dan harapan diri yang negatif yang dengan pengalaman tersebut cenderung lebih dulu menyerang orang lain sebelum diserang. Bullying dimaknai sebagai sebuah kekuatan melindungi diri dari lingkungan (keluarga) yang mengancam, 2) faktor sekolah: karena pihak sekolah sering mengabaikan keadaan bullying, anak-anak sebagai pelaku bullying mendapatkan penguatan terhadap perilaku untuk melakukan intimidasi kepada anakanak

Bullying berkembang dengan pesat dalam lingkungan sekolah, sering memberikan masukan negatif pada siswa lain, berupa hukuman yang tidak membangun sehingga tidak mengembangkan rasa menghargai dan menghormati antar siswa, 3) faktor kelompok sebaya: anak-anak ketika berinteraksi dalam sekolah dan dengan teman sekitar sekolah kadangkala terdorong melakukan bullying. Kadangkala beberapa anak melakukan bullying pada anak lainnya dalam usaha membuktikan diri bisa masuk dalam kelompok tertentu, meskipun mereka sendiri merasa tidak nyaman dalam perilaku tersebut.

Korban bullying ataufictim adalah seseorang yang berulangkali mendapatkan perlakuan agresi dari kelompok sebaya naik dalam bentuk serangan fisik, atau serangan verbal, atau bahkan kekerasan psikologis. Biasanya yang menjadu korban bullying pada kelompok laki-laki adalah mereka yang lemah secara fisik dibandingkan dengan kelompok sebayanya. Mereka yang menjadi korban bullying, menurut penelitian adalah kebanyakan dari keluarga atau sekolah yang sangat over protektif sehingga anak atau siswa tidak dapat mengembangkan secara maksimal kemampuan memecahkan masalah sendiri (coping skill).

Ronbanks dalam artikelnya bullying in school, mengungkapkan bahwa siswa korban bullying menunjukkan beberapa gejala, 
misalnya cemas, rasa selalu tidak aman, sangat berhati-hati, dan mereka menunjukkan harga diri yang rendah (low self-esteem). Mereka juga memiliki interaksi social yang rendah dengan teman-temannya, kadangkala mereka termasuk anak yang diisolasi oleh teman sebayanya.

Konsekuensi adalah sebuah kata yang tepat untuk menggambarkan bagaimana dan apa yang bisa terjadi di balik perilaku bullying ini. Pada artikel Ronbanks pada tahun 1997 dipaparkan sebuah penelitian di Skandinavia bahwa ada korelasi kuat antara bullying yang dilakukan siswa selama beberapa tahun sekolah di mana meeka menjadi pelaku kriminal di saat dewasa. Ini adalah adalah sebuah penelitan yang memberikan gambaran bagaimana bullying dapat membentuk sebuah kepribadian yang dapat menempatkan seorang anak pada sebuah perjalanan dan pengalaman hidup yang kelam.

Sedangkan sebagai korban bullying sering mengalami ketakutan ke sekolah dan tidak percaya diri, merasa tidak nyaman, dan tidak bahagia. Aksi bullying menyebabkan seseorang terisolasi dari kelompok sebayanya karena teman sebaya korban bullying tidak mau akhirnya mereka menjadi target bullying karena mereka berteman dengan korban bullying.

Bullying sudah menjadi masalah global yang tidak bisa diabaikan lagi. Banyak hal yang harus dilakukan untuk menyelamatkan perkembangan psikologis anak-anak dan remaja. Kekerasan sejak dini bukan merupakan bagian dari perkembangan psikologis mereka, oleh sebab itu banyak elemen harus ikut terlibat, baik orang tua, pihak sekolah, bahkan pemerintah. Beberapa hal yang bisa dilakukan untuk mencegah antara lain: 1) orang tua membiasakan diri memberikan feed back positif bagi anak sehingga mereka belajar berperilaku sosial yang baik dan baik dan mendapatkan model interaksi yang tepat, bukan seperti perilaku bullying dan agresi. Menggunakan alternative hukuman kepada anak dengan tidak melibatkan kekerasan fisik maupun psikologis. Selain itu, orang tua mau menjalin relasi dan konsultasi dengan pihak sekolah jika anaknya menjadi pelaku bullying ataupun korban. 2) pihak sekolah menciptakan lingkungan yang positif dan kondusif, misalnya dengan mengadakan praktik kedisiplinan tanpa menggunakan hukuman kekerasan. Tak kalah pentinya meningkatkan kesadaran pihak sekolah untuk tidak mengabaikan perilaku bullying di lingkungan sekolah.

Lalu bagaimanakah upaya-upaya yang perlu dilakukan oleh guru dan orang tua untuk menghadapi hal itu?

a. Cermati gejala-gejala perubahan anak, dan segeralah lakukan pendekatan padanya

b. Tenanglah dalam bertindak, sambil meyakinkan anak bahwa ia telah mendapat perlindungan dari perilaku bullying mendatang

c. Laporkan kepada guru/ pihak sekolah untuk segera dilakukan penyelidikan

d. Meminta konselor ( guru BK) sekolah melakukan penyelidikan tentang apa yang telah terjadi

e. Meminta pihak sekolah untuk memberikan info tentang apa yang sebenarnya telah 
terjadi

f. Mengajarkan anak cara-cara menghadapi bullying

Strategi Menghadapi Bullying di sekolah adalah:

a. Ajarkan siswa untuk menyembunyikan kemarahan atau kesedihannya. Bila ia tampak bereaksi si bullying akan senang

b. Ajarkan anak berani memandang mata si bullying

c. Ajarkan anak berdiri tegak, kepala ditegakkan dalam menghadapi bullying

d. Tidak berjalan sendirian

e. Tetap tenang dalam situasi apapun

f. Bila dalam bahaya segera menyingkir.

\section{KESIMPULAN}

Bullying akan senantiasa terjadi dan sering tidak mendapatkan perhatian dari para guru karena peristiwa ini dianggap hal biasa dan wajar, namun jika diperhatikan lebih lanjut sebenarnya bullying sangat banyak memberikan dampak negatif pada diri korban. Peran guru dan pembimbing di sekolah sangat penting untuk meminimalisirnya agar siswasiswa di sekolah dapat berkembang dengan wajar dalam suasana gembira tidak dengan ketakutan. Tulisan di atas semoga membantu para orang tua, guru, dan konselor dalam menghadapi bullying yang terjadi di sekolah. Semoga bullying tak terjadi lagi di sekolahsekolah kita, apabila kita mampu melakukan pengawasan.

\section{REFERENSI}

Anonim. 2002. Bullying and Problem Disorder . New York: Mc Graw Hill.
2011. Psikologi Plus volume $V$ no.3.

Semarang. 